\title{
УДК 159.943
}

DOI 10.32626/2413-2578.2020-16.257-267

\author{
А.В. Сімко \\ 7kort@ukr.net \\ https://orcid.org/0000-0002-6197-9086
}

\section{ОСОБЛИВОСТІ СТВОРЕННЯ ПОРІВНЕВО- ЗБАЛАНСОВАНОЇ ПРОГРАМИ КОРЕКЦЇ̈ ПСИХОМОТОРИКИ МОЛОДШИХ ШКОЛЯРІВ 3 ОСОБЛИВИМИ ОСВІТНІМИ ПОТРЕБАМИ}

Відомості про автора: Сімко Алла Володимирівна, кандидат психологічних наук, старший викладач кафедри логопедії та спеціальних методик Кам'янець-Подільського національного університету імені Івана Огієнка, Кам'янець-Подільський, Україна. У колі наукових інтересів: проблеми корекції психомоторного розвитку та дослідження психомоторної активності дітей дошкільного віку 3 порушеннями психофізичного розвитку. E-mail: 7kort@ukr.net

Contakt: Simko Alla, PhD, senior lecturer in speech therapy and special techniques Kamianetz-Podilskiy Ivan Ohienko National University, KamianetzPodilskiy, Ukraine. Academic interests: problems of correction of psychomotor development and research of psychomotor activity of children of preschool age with psychophysical development violations. E-mail: 7kort@ukr.net

Відомості про наявність матеріалів по темі статті: 1. Сімко А.В. Особливості розвитку психомоторної активності дітей. Актуальні питання корекційної освіти (педагогічні науки): збірник наукових праць: вип.9, у 2 т. / за ред. В.М. Синьова, О.В. Гаврилова. Кам'янець-Подільський: ПП Медобори-2006, 2017. T.2 (Index Copernicus). 2. Сімко А.В. До питання про особливості психомоторних дій у дітей молодшого дошкільного віку 3 тяжкими порушеннями психофізичного розвитку. Актуальні питання корекційної освіти (педагогічні науки): збірник наукових праць: вип.10, у 2 т. / за ред. В.М. Синьова, О.В. Гаврилова. Кам'янець-Подільський: ПП Медобори-2006, 2017. Т.2. (Index Copernicus). 3. Сімко А.В. Особливості діагностики та корекції психомоторного розвитку дошкільників 3 інтелектуальними порушеннями на заняттях фізичного виховання. Актуальні питання корекційної освіти (педагогічні науки): збірник наукових праць: вип.12, у 2 т. / за ред. В.М. Синьова, О.В. Гаврилова. Кам'янець-Подільський: ПП Медобори-2006, 2018. Т.2. (Index Copernicus).

Сімко А.В. Особливості створення порівнево-збалансованої програми корекції психомоторики молодших школярів з особливими 
освітніми потребами. В статті розглянуто особливості підходу до створення корекційно-розвивальної програми психомоторики дітей 3 особливими освітніми потребами молодшого шкільного віку. Створення програми було здійснено на основі урахування психомоторних можливостей суб'єкта активності на різних рівнях побудови рухів. Програма має структуру відповідну рівням побудови рухів і передбачає збільшення орієнтувально-дослідницьких можливостей дітей з особливими освітніми потребами. Проведено теоретичний аналіз наукових досліджень щодо проблеми корекції психомоторики у дітей з особливими освітніми потребами. Визначено, що формування активної особистості в молодшому шкільному віці зумовлюється різними соціальними та психологопедагогічними чинниками, серед яких вагоме місце посідають психомоторні можливості. У психомоторних проявах встановлюється реальний зв'язок дитини з соціальним середовищем в якому і формується особистість. Описано програму, яка реалізує авторську модель організації умов розвитку психомоторних можливостей дітей з особливими освітніми потребами молодшого шкільного віку. Розробку програми було здійснено на основі констатувального експерименту щодо психомоторних можливостей суб'єкта психомоторної активності на різних рівнях побудови рухів. Програма має чітку структуру, перевірку ії ефективності здійснено на експериментальній та контрольній групах дітей. Зроблено висновок, що варіативність смислових завдань та умов їх виконання дозволяє збільшити орієнтувальну активність дитини спрямовану на пошук ефективніших рухів, сенсорних синтезів і центральних механізмів управління психомоторною дією.

Ключові слова: діти з особливими освітніми потребами, корекція, психомоторика, порівнево-збалансована програма.

\section{Симко А.В. Особенности создания поуровнево-сбалансированной программы коррекции психомоторики младших школьников с} особыми образовательными потребностями. В статье рассмотрены особенности подхода к созданию коррекционно-развивающей программы психомоторики детей с особыми образовательными потребностями младшего школьного возраста. Создание программы было осуществлено на основе учета психомоторных возможностей субъекта активности на различных уровнях построения движений. Программа имеет структуру, которая соответствует уровням построения движений и предусматривает увеличение ориентировочно-исследовательских возможностей детей с особыми образовательными потребностями. Проведен теоретический анализ научных исследований по проблеме коррекции психомоторики у детей с особыми образовательными потребностями. Определено, что формирование активной личности в младшем школьном возрасте обусловлено различными социальными и психолого-педагогическими факторами, среди которых важное место занимают психомоторные возможности. В психомоторных проявлениях устанавливается реальная 
связь ребенка с социальной средой в котором и формируется личность. Описано программу, которая реализует авторскую модель организации условий развития психомоторных возможностей детей с особыми образовательными потребностями младшего школьного возраста. Разработку программы было осуществлено на основе констатирующего эксперимента на основе психомоторных возможностей субъекта и психомоторной активности на различных уровнях построения движений. Программа имеет четкую структуру, проверка ее эффективности осуществлена на экспериментальной и контрольной группах детей. Сделан вывод, что вариативность смысловых задач и условий их выполнения позволяет увеличить ориентировочную активность ребенка направленную на поиск эффективных движений, сенсорных синтезов и центральных механизмов управления психомоторной действием.

Ключевые слова: дети с особыми образовательными потребностями, коррекция, психомоторика, поуровнево-сбалансированная программа.

Simko A.V. Features of creation of a correction comparativelybalanced program of psychomotor of the younger students with special educational needs. The article deals with the peculiarities of the approach to the creation of the correction and developmental program of psychomotor of children with special educational needs of younger school age. The creation of the program was carried out on the basis of the psychomotor capabilities of the subject of activity at different levels of motion construction. The program has a structure appropriate to the levels of movement development and envisages an increase in the orientation and research capacity of children with special educational needs. Theoretical analysis of scientific researches on the problem of psychomotor correction of children with special educational needs is carried out. It has been determined that the formation of an active personality in younger school age is conditioned by various social and psychologicalpedagogical factors, among which psychomotor opportunities occupy a significant place. Psychomotor manifestations establish a real connection of the child with the social environment in which the personality is formed. It's described a program that implements the author's model of organizing the conditions for the development of psychomotor abilities of children with special educational needs of younger school age. The development of the program was carried out on the basis of a statement experiment on the psychomotor capabilities of the subject of psychomotor activity at different levels of motion construction. The program has a clear structure, and its effectiveness was tested on the experimental and control groups of children. The program was implemented in several stages: preparatory, basic, final. The preparatory phase of the program involved a comprehensive determination of the psychomotor capacity of children with special educational needs at different levels of motion development; development of specific goals and objectives, strategies of psycho-corrective work; drawing up a work plan for the formation of a kind of 
"school" of movements at the involved levels of their construction; creation of the necessary material and technical base for corrective activities.

It is concluded that the variability of semantic tasks and conditions of their performance allows to increase the orienting activity of the child aimed at finding more efficient movements, sensory syntheses and central mechanisms of control of psychomotor action. The comparatively balanced program takes into account that the most effective influence on the correction of psychomotor abilities of preschool-aged children is not by individual exercises, but by their complex, which provides finding compensatory ways of motion control.

Key words: children with special educational needs, correction, psychomotor, comparatively balanced program.

Постановка проблеми. Вивчення психомоторики дітей 3 особливими освітніми потребами дає підстави стверджувати, що незалежно від особливостей моторної недорозвиненості, всім їм притаманні значні труднощі при виконанні завдань, що потребують змінити засвоєнні рухи. Оскільки спроможність відійти від одного разу знайденого і засвоєного руху грунтується на орієнтувально-дослідницьких можливостях психомоторики суб'єкта, то саме порушення останніх і $є$ центральною ланкою відповідної патології $[4 ; 5]$.

Водночас корекція спроможності змінювати свої психомоторні стереотипи, формування ефективних орієнтувально-дослідницьких рухів у дітей відіграє особливо важливу роль в їх адаптації до навколишнього середовища. Проте завдання щодо корекції можливості диференціювати рухи $є$ досить складним і вимагає визначення відповідних психологопедагогічних засад цієї роботи, що є важливим науковим і практичним завданням $[6 ; 7 ; 9]$.

Аналіз останніх досліджень і публікацій. Розв'язання цієї проблеми започатковане у працях М. Бернштейна, О. Запорожця, які досліджували психомоторику як складне ієрархічне утворення низки рівнів побудови рухів і запропонували систематизувати з цих позицій патологію реалізації рухової функції, а також вивчати психіку як орієнтувальнодослідницьку діяльність. В сучасних дослідженнях розуміння таких особливостей функціонування психомоторики підтверджується $[6 ; 10 ; 11$; 12]. В сучасній літературі механізм інтеріоризації та екстеріоризації м'язової та психічної, або психомоторної активності, описують такі психологи як В. Клименко, О. Малхазов, В.П. Озеров. На те, що саме дія породжує психіку, вказували такі вчені, як С. Рубінштейн, О. Леонтьєв, П. Гальперін, Д. Ельконін, В. Давидов та багато інших. Проте залишається недостатньо дослідженою можливість проведення корекційної роботи на цій основі у дітей 3 особливими освітніми потребами молодшого шкільного віку.

Мета статті - окреслити психолого-педагогічні засади розробки програми корекції психомоторних можливостей дітей 3 особливими 
освітніми потребами 7-8 років на основі порівневого підходу до побудови рухів та дослідження психіки як орієнтувальної активності. Запропонувати порівнево-збалансовану програму корекції психомоторики у дітей старшого дошкільного віку.

Виклад основного матеріалу. Проведені нами теоретичні та емпіричні дослідження можливостей удосконалення програм корекції психомоторного розвитку дітей дошкільного віку дозволяють стверджувати, що ці програми доцільно розробляти, насамперед, на основі психофізіологічних наукових поглядів М. Бернштейна [1; 2]. Автор здійснив ряд досліджень, які експериментально довели, що організм $\epsilon$ активною цілеспрямованою системою, а не реактивною системою, яка тільки пасивно відповідає на зовнішні впливи та пристосовується до навколишнього середовища. Активність організму спрямована на задоволення потреб, на досягнення певної мети. Тобто, на подолання навколишнього середовища, а не на урівноважування 3 ним. Це негентропійна система, вона протидіє ентропії. Відповідно і корекційні програми мають враховувати цю активність, яка дозволяє індивіду стати суб'єктом.

Водночас дослідження реалізації психомоторної функції людиною за допомогою точних апаратурних методик однозначно довели, що при повторенні дій неможливо абсолютно точно повторити рухи. Наприклад, виконуючи удар молотком по зубилу робітник щоразу точно попадає по ньому, проте рухи ланок тіла в кожному ударі відрізняються за своїми траєкторіями. Отже, повторюється тільки завдання, а «накази» нервової системи м'язам мають змінюватися із врахуванням конкретних, реальних умов виконання дії. Більше того $є$ відповідність між «образом потрібного майбутнього» і результатом дії, а не відповідність між результатом рухів і «наказами», що ідуть від мозку до м'язів. Останнє пояснюється значною складністю будови рухового апарату та силового поля дії. Описану закономірність «повторення без повторення» також необхідно враховувати при розробці нових програм психомоторного розвитку дітей.

Для реалізації рухової функції мозок людини не тільки надсилає певні «накази» м'язам, а й отримує від аналізаторів інформацію про результати виконання цих «наказів» і порівнявши їх з «образом потрібного майбутнього» дає нові корегуючі «накази», які спрямовані на подолання відхилень реальних рухів від бажаних. Іншими словами, існує не тільки прямий зв'язок (мозок - м'язи), а й зворотній (м'язи, смислові аналізатори - мозок). I це експериментально доведене М. Бернштейном положення щодо механізмів регуляції рухів має обов'язково враховуватись в нових програмах корекції психомоторики.

Грунтовно дослідив вчений i те, що для побудови рухів різної складності суб'єкт психомоторної активності віддає «накази» на ієрархічно різних рівнях центральної нервової системи. Побудова рухів це система всіх сенсорних синтезів, що приймають участь в координуванні певної дії 
та система еферентних імпульсів в їх єдності. Побудова рухів реалізується п'ятьма рівнями, кожен з яких $\epsilon$ провідним для вирішення певного класу психомоторних завдань, інші рівні (коли один з них взяв на себе функцію провідного) виконують фонові функції. Зазвичай робота фонових рівнів не усвідомлюється.

Створення нових програм корекції психомоторних можливостей дітей молодшого шкільного віку також має враховувати те, що експериментально довів О. Запорожець - в основі будь-якого пізнавального процесу дитини є практичні дії. Онтогенетичні дослідження автора однозначно довели, що сприймання це згорнута перцептивна дія. Мислення також першопочатково є практичним узагальненням (наочнодійове мислення). Інтеріоризація розумілась Запорожцем О. як перетворення у внутрішне першопочатково зовнішньої орієнтувальної діяльності. Більш того, сама психіка досліджувалась автором як орієнтувально-дослідницька діяльність, що було значним доробком до створення в психології теорії діяльності [8].

Отже теоретико-методологічними засадами розробки програм корекції психомоторики дітей можуть бути положення М. Бернштейна про: активність живих систем, неможливість точного повторення рухів в діях, необхідність зворотного зв'язку і корекцій в керуванні рухами, ієрархію рівнів побудови рухів (кожен з яких є провідним для вирішення певного класу психомоторних завдань). Та положення О. Запорожця про те, що: в основі пізнавальних процесів дитини є практичні дії, психіка може досліджуватись як орієнтувально-дослідницька діяльність, онтогенетично зумовлені особливості виникнення і розвитку довільних рухів і дій та формування на їх основі особистості.

Корекційна програма реалізує авторську модель організації умов розвитку психомоторних можливостей дітей 3 особливими освітніми потребами молодшого шкільного віку. Розробку програми було здійснено на основі констатувального експерименту щодо психомоторних можливостей суб'єкта психомоторної активності на різних рівнях побудови рухів. Програма має чітку структуру, перевірку ії ефективності здійснено на експериментальній та контрольній групах дітей. Цілями i завданнями програми було:

- здійснення ефективного комплексного визначення психомоторних можливостей дітей 3 особливими освітніми потребами молодшого шкільного віку на різних рівнях побудови рухів;

- прогнозування оптимального збалансованого поєднання корекційних вправ для покращення психомоторних можливостей дітей 7-8 років зі стійкими органічними порушеннями пізнавальної діяльності;

- створення необхідних умов для корекції психомоторних можливостей на чотирьох рівнях побудови рухів дітей 3 особливими освітніми потребами молодшого шкільного віку; формування рухів дітей 
на задіяних рівнях реалізації їх рухової функції; створення умов для включення компенсаторних механізмів керування рухів;

- забезпечення умов для закріплення досягнених результатів та позитивних змін і переносу їх у реальну життєдіяльність дітей.

Реалізація програми здійснювалась у кілька етапів: підготовчий, основний, заключний. Підготовчий етап програми передбачав комплексне визначення психомоторних можливостей дітей з особливими освітніми потребами на різних рівнях побудови рухів; розробку конкретних цілей і завдань, стратегій психокорекційної роботи; складання плану роботи щодо формування своєрідної «школи» рухів на задіяних рівнях їх побудови; створення необхідної матеріально-технічної бази для проведення корекційних занять.

Основний етап включав у себе безпосередню реалізацію програми у відповідності зі структурними компонентами моделі корекції психомоторних можливостей дітей з особливими освітніми потребами на рівнях побудови рухів. Структурно-функціональна модель корекції психомоторних можливостей являє собою визначену у часі послідовність дій із зазначенням функціональних зв'язків між різними рівнями.

У корекційну програму на основному етапі включено комплекс ігрових вправ, які забезпечують зміст впливу на психомоторику з метою іiі корекції.

Спостереженнями встановлено, що найбільш ефективний вплив на корекцію психомоторних можливостей дітей 3 особливими освітніми потребами молодшого шкільного віку мають не окремі вправи, а їх комплекс, який забезпечує віднаходження компенсаторних шляхів керування рухами.

Для розв'язання завдань основного етапу корекції використовувались спеціальні вправи програми.

Корекцію психомоторних можливостей доцільно здійснювати, якщо це можливо, насамперед на провідному рівні. 3 цією метою можна застосувати виконання тих дій для яких конкретний рівень $є$ провідним у варіативних умовах. Штучно створені умови варіативності збільшать орієнтувально-дослідницьку активність суб'єкта, та покращать функціональні можливості рівня побудови рухів. Зміна кінематичних i динамічних характеристик рухів може здійснюватися у процесі виконання побутових дій, фізичних вправ та в інших умовах [13].

В умовах коли міра ураження певних ділянок центральної нервової системи $\epsilon$ такою, що виконати дії по вирішенню одного 3 класів психомоторних завдань неможливо пропонується змінювати субординацію рівнів. Тобто пропонується так змінити смислові завдання, щоб керування дією перейшло на більш збережений рівень. Проте цей шлях $є$ більш складним і не таким ефективним як попередній. Далеко не завжди вдається віднайти обхідні шляхи, що дозволять сформувати нові психологічні механізми керування конкретними діями [3]. 
Загалом, здатність психіки до компенсацій у дітей може бути знижена i надзвичайно важливо розпочати здійснювати корекцію їх психомоторних можливостей вчасно. Своєчасно розпочата корекційна робота дозволяє максимально повно розвити функціональні можливості індивідуально збережених церебральних систем, психічних пізнавальних процесів і психомоторних якостей.

Отже, основними засадами методу порівнево-збалансованої корекції психомторики дітей 3 особливими освітніми потребами молодшого шкільного віку є:

1. Центральною ланкою порушень психомоторного розвитку дітей молодшого шкільного віку є їх знижена спроможність до перебудови засвоєних рухів i дій, що зумовлюється порушенням відчуттів, орієнтувально-дослідницьких можливостей. Відтак ускладняються i специфічно змінюються умови формування психомоторних якостей суб'єкта.

2. Патологія психомоторного розвитку у дітей настільки різноманітна, що іiі складно класифікувати. Складно в індивідуальносвоєрідних «мозаїках» ушкоджень центральної нервової системи віднайти системоутворюючі чинники. Найбільш обгрунтованою, на нашу думку, $є$ класифікація психомоторних порушень у відповідності з рівнями побудови рухів.

3. Програми корекції психомоторних можливостей дітей молодшого шкільного віку доцільно будувати саме так, щоб вони включали різні дії провідними для яких $\epsilon$ різні рівні побудови рухів, a їх виконання передбачало доцільні зміни кінематичних та динамічних характеристик. Зазначені умови будуть максимально сприяти залученню до реалізації рухової функції індивідуально збережених можливостей дитини, розвитку психічних пізнавальних процесів, формуванню психомоторних якостей.

4. Психолого-педагогічними засадами розробки таких корекційних програм $є$ положення наукових концепцій М. Бернштейна про: організм як активну цілеспрямовану систему, неможливість абсолютно точно повторити свої рухи, неоднозначність між м'язовими імпульсами та результуючими рухами, необхідність прямого і зворотного зв'язку та корекцій для керування рухами, рівні побудови рухів.

5. Науковими засадами для розробки програм корекції психомоторики є також положення О. Запорожця про те, що: в основі розвитку психічних пізнавальних процесів дитини є практичні дії, психіка може досліджуватись як орієнтувально-дослідницька діяльність, в онтогенезі розвитку довільних рухів і дій формується особистість.

Корекцію функціональних можливостей дітей на рівні А (тонусу) доцільно здійснювати шляхом ігор в яких передбачено короткочасне збереження заданих поз з плавними незначними змінами їх кінематичних i динамічних характеристик. Наприклад, наслідування позам тварин. Невеликі, але такі, що відчуваються зміни розташування ланок тіла в просторі сприятимуть включенню нових м'язових синергій, змінюючи тонус всіх задіяних в збереженні поз (статичної рівноваги) груп м'язів. 
Корисними будуть вправи по розвитку заданих м'язових зусиль, особливо коли свідчення динамометрів виведені на екран комп'ютера і графічно представлені (торкання предметом іграшки тощо).

Корекцію функціональних можливостей психомоторики дітей на рівні В (м'язово-суглобових ув'язок) можна здійснювати шляхом застосуванням всіляких вправ по утриманню динамічної рівноваги тіла $\mathrm{i}$ включених в ігрові ситуації. Корисними будуть вправи по розвитку точності відтворення просторових і часових характеристик рухів без зорового контролю.

Корекцію функціональних можливостей психомоторики дітей на рівні С (простору) доцільно здійснювати шляхом використання всіляких вправ для виконання яких дитині необхідна просторова точність рухів (при зоровому контролі). Наприклад, стрибки на визначену відміткою відстань, метання м'ячика в ціль тощо (збільшуючи і зменшуючи відстань від оптимальної).

Корекцію функціональних можливостей дітей на рівні $\mathrm{D}$ (дій) доцільно здійснювати шляхом актуалізації нових аспектів вже відомих дій 3 предметами культури, що сприяе також розвитку узагальненості розумової діяльності.

Корекцію функціональних можливостей психомоторики на найвищому кортикальному рівні Е (мовлення і письма) в молодшому шкільному віці можна лише частково. Наприклад, синхронізація моторних і словесних компонентів дій, доступна словесна характеристика своїх pyxiв.

Застосування запропонованої порівнево збалансованої коректувальної програми основується на тому, що діти з особливими освітніми потребами молодшого шкільного віку мають різні успіхи в керуванні рухами на різних рівнях їх побудови, що залежить від індивідуально-своєрідних порушень центральної нервової системи. В цілому, програма дає можливість використовувати збережену пропріорецептивну чутливість дитини.

Досвід практичної роботи i теоретичні дослідження, як вже зазначалось, дають підстави констатувати той факт, що всі діти 3 особливими освітніми потребами, незалежно від особливостей психомоторного недорозвинення і міри стійкого органічного порушення пізнавальної діяльності, зазнають значних труднощів при виконанні завдань, що вимагають зміни раніше завчених рухів і дій.

Варіативність смислових завдань і умов їх виконання дозволяє збільшити орієнтувальну активність дитини спрямовану на пошук ефективніших рухів, сенсорних синтезів i центральних механізмів управління психомоторною дією. У складній ієрархії рівнів побудови рухів відшукується оптимальний варіант їх спільної роботи, при необхідності формуються нові компенсаторні функціональні органи i механізми керування діями. У той ж час необхідно підкреслити, що не йдеться про повне виправлення складних порушень психомоторики або про повне відновлення м'язової чутливості, а лише про індивідуально можливе 
збільшення спроможності керувати рухами шляхом включення пропріорецептивної чутливості, що збереглася.

Об'єднання положень різних дисциплін в єдину систему міждисциплінарного підходу до корекції психомоторики дітей 3 особливими освітніми потребами молодшого шкільного віку дозволило запропонувати для практики порівнево збалансовану коректувальну програму оптимізації існуючих і утворення нових функціональних органів.

Висновки. Проведені нами теоретичні та емпіричні дослідження можливостей удосконалення програм корекції психомоторного розвитку дітей молодшого шкільного віку дозволяють стверджувати, що ці програми доцільно розробляти, насамперед, на основі психофізіологічних наукових поглядів М. Бернштейна. Розробка нових програм корекції психомоторних можливостей дітей молодшого шкільного віку також має враховувати те, що експериментально довів О. Запорожець - в основі будьякого пізнавального процесу дитини $є$ практичні дії. Порівневозбалансована програма враховує, що найбільш ефективний вплив на корекцію психомоторних можливостей дітей 3 особливими освітніми потребами мають не окремі вправи, а їх комплекс, який забезпечує віднаходження компенсаторних шляхів керування рухами. Корекцію конкретних психомоторних можливостей доцільно здійснювати, якщо це можливо, насамперед на провідному рівні. Варіативність смислових завдань і умов їх виконання дозволяє збільшити орієнтувальну активність дитини спрямовану на пошук ефективніших рухів, сенсорних синтезів i центральних механізмів управління психомоторною дією.

\section{Бібліографія}

1. Бернштейн Н.А. (1947). О построении движений. Москва: Медгиз. 2. Бернштейн Н.А. (1996) Очерки по физиологии движений и физиологии активности. Москва: Медецина. 3. Бех І.Д. (1995). Теоретичні засади навчання і розвитку аномальних дітей. Педагогіка і психологія. 4. Вайзман Н.П. (1976). Психомоторика детей олигофренов. Москва: Педагогика. 5. Венгер Л.А. (1981). О формировании познавательных способностей в процессе обучения дошкольников. Москва: Издательство Московского университета. б. Гордеева Н.Д. (1995). Экспериментальная психология исполнительного действия. Москва: Тривола. 7. Гуровец Г.В. (1999). Методика реабилитации психомоторных нарушений у умственно отсталых школьников на занятиях ЛФК. Дефектология. №1. 8. Запорожец A.B. (1986). Избранные психологические труды. Москва: Педагогика. 9. Козленко М.О. (1996). Розвиток пізнавальної самостійності учнів допоміжної школи в процесі навчання рухових дій. Дефектологія. №2. 10. Клименко В.В. (1997). Механізми психомоторики людини. Київ. 11. Малхазов О.Р. (2002). Психологія та психофізіологія управління руховою діяльністю. Київ: Свролінія. 12. Озеров В.П. (2002). Психомоторные способности человека. Дубна: Феникс. 13. Сімко А.В. (2014). Корекція психомоторики дітей- олігофренів дошкільного віку. Монографія. Кам’янець-Подільський: ТОВ «Друк-Сервіс». 


\section{References}

1. Bernshtejn N.A. (1947). O postroenii dvizhenij. Moskva: Medgiz. [in Russian]. 2. Bernshtejn N.A. (1996) Ocherki po fiziologii dvizhenij i fiziologii aktivnosti. Moskva: Medecina [in Russian]. 3. Bekh I.D. (1995). Teoretichni zasadi navchannya i rozvitku anomal'nih ditej. Pedagogika i psihologiya. [in Ukrainian]. 4. Vajzman N.P. (1976). Psihomotorika detej oligofrenov. Moskva: Pedagogika [in Russian]. 5. Venger L.A. (1981). O formirovanii poznavatel'nyh sposobnostej $\mathrm{V}$ processe obucheniya doshkol'nikov. Moskva: Izdatel'stvo Moskovskogo universiteta [in Russian]. 6. Gordeeva N.D. (1995). Eksperimental'naya psihologiya ispolnitel'nogo dejstviya. Moskva: Trivola [in Russian]. 7. Gurovec G.V. (1999). Metodika reabilitacii psihomotornyh narushenij u umstvenno otstalyh shkol'nikov na zanyatiyah LFK. Defektologiya. №1 [in Russian]. 8. Zaporozhec A.V. (1986). Izbrannye psihologicheskie trudy. Moskva: Pedagogika [in Russian]. 9. Kozlenko M.O. (1996). Rozvitok piznaval'noï samostijnosti uchniv dopomizhnoï shkoli v procesi navchannya ruhovih dij. Defektologiya. №2 [in Ukrainian]. 10. Klimenko V.V. (1997). Mekhanizmi psihomotoriki lyudini. Kiïv [in Ukrainian]. 11. Malhazov O.R. (2002). Psihologiya ta psihofiziologiya upravlinnya ruhovoyu diyal'nistyu. Kiïv: Evroliniya [in Ukrainian]. 12. Ozerov V.P. (2002). Psihomotornye sposobnosti cheloveka. Dubna: Feniks [in Russian]. 13. Simko A.V. (2014). Korekciya psihomotoriki ditej- oligofreniv doshkil'nogo viku. Monografiya. Kam'yanec'Podil's'kij: TOV «Druk-Servis» [in Ukrainian].

Дата відправлення статті 22.02.2020 р.

Утьосов Я.А. arnst99@gmail.com https://orcid.org/0000-0002-3839-7803

\section{ОСОБЛИВОСТІ ПРОВІДНОЇ ДІЯЛЬНОСТІ ПІДЛІТКІВ 3 ІНТЕЛЕКТУАЛЬНИМИ ПОРУШЕННЯМИ В КОНТЕКСТІ ФОРМУВАННЯ У НИХ СОЦІАЛЬНИХ КОМПЕТЕНТНОСТЕЙ}

Відомості про автора: Утьосов Ян Андрійович, аспірант кафедри корекційної педагогіки та інклюзивної освіти Кам'янець-Подільського національного університету імені Івана Огієнка, м. Кам'янецьПодільський, Україна. У колі наукових інтересів: організація корекційної діяльності педагога в умовах спеціальної та інклюзивної освіти; проблема 